\title{
Pembelajaran Daring Mahasiswa Tadris Matematika dengan Menerapkan E-Learning di Tengah Pandemi Covid-19
}

\author{
Vivin Agustin Anggraini ${ }^{1}$ ), Nur Mauliska ${ }^{2}$ ), Mar'atus Sholehah ${ }^{3}$ ) \\ $\left.{ }^{1}\right)$ Dosen Tadris Matematika, Fakultas Tadris Umum Universitas Islam Zainul Hasan Genggong \\ $\left.{ }^{2}\right)$ Mahasiswa Tadris Matematika, Fakultas Tadris Umum Universitas Islam Zainul Hasan Genggong \\ $\left.{ }^{3}\right)$ Mahasiswa Tadris Matematika, Fakultas Tadris Umum Universitas Islam Zainul Hasan Genggong \\ Email: vivinagustinanggraini.inzah@gmail.com
}

\begin{abstract}
s
This study aims to determine the effectiveness of online learning for Tadris Mathematics students in the midst of the Covid-19 pandemic. This type of research is a qualitative descriptive method with an online questionnaire filled out by Mathematics Tadris students at the Islamic University of Zainul Hasan Genggong. The methods used are observation, structured interviews through questionnaire filling. The data analysis technique used qualitative descriptive analysis method, namely, data reduction, presentation and conclusion drawing. The results indicated that students understood online learning (online) using e-learning during the Covid-19 pandemic.
\end{abstract}

\section{Keyword : online learning; student of mathematic education; e-learning}

\begin{abstract}
Abstrak
Penelitian ini bertujuan untuk mengetahui efektifitas pembelajaran daring mahasiswa Tadris Matematika di tengah pandemic Covid-19. Jenis penelitian ini adalah metode deskriptif kualitatif dengan kuesioner online yang diisi oleh mahasiswa Tadris Matematika Universitas Islam Zainul Hasan Genggong. Metode yang digunakan adalah observasi wawancara terstruktur melalui pengisian kuesioner. Teknik analisis data dengan metode analisis deskriptif kualitatif yakni reduksi data, sajian dan penarikan kesimpulan. Hasil penelitian mengindikasikan bahwa mahasiswa memahami dalam pembelajaran daring (dalam jaringan) dengan menggunakan e-learning selama pandemi Covid-19.
\end{abstract}

\section{Kata Kunci : pembelajaran daring; mahasiswa tadris matematika; e-learning}

\section{PENDAHULUAN}

Latar belakang dari penelitian ini adalah untuk mengetahui efektifitas pembelajaran daring mahasiswa Tadris Matematika dengan penerapan e-learning di Universitas Islam Zainul Hasan Genggong selama pandemi Covid-19. Perkembangan teknologi informasi dan komunikasi yang semakin pesat beberapa tahun terakhir mendapat sambutan positif di kalangan pelajar terutama mahasiswa. Seperti yang terlihat saat ini, berbagai layanan pendidikan telah menerapkan ICT.

Dunia pendidikan di Indonesia yang semakin berkembang terlihat dari semakin beragamnya metode atau model pembelajaran yang digunakan. Metode atau model pemebelajaran tersebut banyak memanfaatkan media untuk meningkatkan hasil pembelajaran mahasiswa di beberapa perguruan tinggi (Hanum, 2013). Seiring perkembangan teknologi informasi (TI) yang semakin pesat, media pembelajaran yang dapat dimanfaatkan dan diterapkan selama pandemi Covid-19 (Corona Virus Disease) adalah menggunakan pembelajaran dalam jaringan (daring) atau e-learning (Pratama, 2016).

E-learning merupakan pembelajaran jarak jauh yang menggunakan teknologi salah satunya yaitu internet. Horton (2003) menjelaskan e-learning merupakan pembelajaran berbasis web yang bisa diakses dengan menggunakan internet. E-learning merupakan salah satu bentuk dari konsep distance learning atau pembelajaran jarak jauh (Indah, 2019). Jadi e-learning atau internet enabled learning menggabungkan metode penyampaian materi dan teknologi sebagai sarana dalam belajar. E-learning bersifat jaringan, yang mampu memperbaiki secara cepat dalam menyimpan, mendistribusikan, dan berbagi konten atau materi pembelajaran dan berbagai informasi (Boyd, 2009). Beberapa perguruan tinggi di Indonesia sudah memiliki fasilitas e-learning tetapi hanya hitungan jari yang menerapkannya. Dengan adanya pandemi Covid-19 saat ini yang mengharuskan mahasiswa belajar dari rumah maka mau tidak mau semua perguruan tinggi wajib menggunakan e-learning atau yang sering disebut dengan pembelajaran dalam jaringan (daring) 
(Mailangkay \& Suharyanto, 2016). Melalui pembelajaran daring, proses belajar dapat dijalankan secara jarak jauh atau diunduh untuk keperluan offline. Mahasiswa dapat mengakses sistem kapan saja tidak ada batasan waktu dan tidak ada batasan tempat. Penelitian ini sangat penting dilakukan mengingat pembelajaran masa pandemi Covid-19 mengharuskan sistem pembelajaran mutlak menggunakan media elektronik.

\section{METODE PENELITIAN}

Dalam penelitian ini, penulis menggunakan penelitian deskriptif kualitatif yaitu dengan mendeskripsikan atau menggambarkan penelitian dengan menggunakan kata-kata. Secara harfiah, penelitian deskriptif adalah peneltian yang bermaksud untuk membuat pencandraan (deskripsi) mengenai situasi-situasi atau kejadiankejadian (Guetterman, 2015). Subjek dalam penelitian ini adalah mahasiswa Tadris Matematika Universitas Islam Zainul Hasan Genggong yang sedang melaksanakan perkuliahan atau pembelajaran daring. Pendekatan penelitian yang digunakan penulis pada penelitian adalah pendekatan pedagogik, yaitu pendekatan yang lebih menekankan pada pendidikan yakni proses pembelajaran yang digunakan oleh pendidik (Miarso, 2004). Untuk menggali informasi mengenai pemahaman mahasiswa dalam pembelajaran daring dengan penerapan e-learning, peneliti melaksanakan wawancara terstruktur yang dilaksanakan secara daring. Peserta diminta untuk menjawab beberapa pertanyaan tentang pemahaman mahasiswa dalam pembelajaran daring dengan penerapan e-learning selama pandemi Covid-19 melalui link web yang telah disediakan oleh peneliti.

\section{HASIL DAN PEMBAHASAN}

Penelitian ini bertujuan untuk mendapatkan informasi mengenai penerapan e-learning selama pandemi Covid-19. Bentuk perkembangan teknologi informasi yang dapat dimanfaatkan sebagai media pembelajaran selama pandemi Covid-19 adalah menggunakan e-learning. E-learning merupakan inovasi yang dapat dimanfaatkan dalam proses pembelajaran. Tidak hanya dalam penyampaian materi pembelajaran, tetapi juga perubahan dalam kemampuan berbagai kompetensi mahasiswa. Melalui e-learning, mahasiswa tidak hanya mendengarkan uraian materi dari dosen atau pengajar saja tetapi juga aktif mengamati, melakukan, mendemonstrasikan, dan sebagainya. Menurut Ahmad (2011), adapun jenis aplikasi e-learning dalam pembelajaran jarak jauh selama pandemi Covid-19 ini, antara lain : 1) Google Classroom, 2) Google Form, Google Sheet, dan Google Drive, 3) Zoom Cloud Meeting, 4) Skype, 5) WhatsApp, 6) Telegram, 7) Moodle. Penelitian ini mengukur keefektifan penerapan e-lerning terhadap kegiatan belajar mengajar mahasiswa Tadris Matematika atau Pendidikan Matematika di perguruan tinggi pada Universitas Islam Zainul Hasan Genggong. Semua tanggapan peserta adalah kutipan asli, dan mereka telah dikutip sebagaimana dinyatakan oleh para responden.

Peserta diminta untuk menjawab beberapa pertanyaan tentang pemahaman mahasiswa dalam pembelajaran daring dengan penerapan e-learning selama pandemi Covid-19 melalui link web yang telah disediakan oleh peneliti.

Adapun pertanyaan yang diajukan saat wawancara secara daring adalah sebagai berikut:

1. Sudahkah Anda melaksanakan pembelajaran daring selama pandemi Covid-19?

2. Setujukah Anda aplikasi sosial media yang biasa Anda gunakan dijadikan sebagai media pembelajaran daring?

3. Setujukah Anda jika menambahkan konten berupa permainan edukatif sebagai media berlatih?

4. Apakah cara dosen menyampaikan konten/materi berupa video, voice note, gambar, atau penjelasan teks mudah dipahami?

5. Puaskah Anda dengan materi yang diberikan oleh dosen selama pembelajaran daring?

6. Menurut Anda, apa yang harus menjadi acuan bahwa mahasiswa Pendidikan Matematika paham dengan materi yang diberikan, dan dosen dapat melanjutkan ke materi selanjutnya?

7. Menurut Anda, apakah aplikasi pembelajaran daring yang sudah ada saat ini sudah cukup membantu?

8. Apakah harus ada aplikasi e-learning lain yang lebih baik dalam memudahkan proses belajar?

9. Apakah menurut Anda sistem pembelajaran daring saat ini sudah memuaskan?

10. Jika Anda diminta untuk memilih, Anda lebih suka pembelajaran daring atau tatap muka?

11. Apa motivasi Anda saat sedang malas mengikuti pembelajaran daring?

12. Apa yang Anda lakukan saat belum memahami materi namun jam kuliah pembelajaran telah selesai? 


\section{Hasil Analisis Deskriptif.}

Dari pertanyaan "Sudahkah Anda melaksanakan pembelajaran daring selama pandemi Covid-19?". 100\% responden menjawab sudah. Artinya, 80 responden telah melakanakan perkuliahan daring selama pandemi Covid-19 saat ini. Dari pertanyaan "Setujukah Anda apabila aplikasi sosial media yang biasa Anda gunakan dijadikan sebagai media pembelajaran daring?". Jika menggunakan aplikasi sosial media yang kita gunakan setiap hari, tentunya dapat menyesuaikan mahasiswa melakukan perkuliahan secara daring dengan mudah. Namun, hanya $81,3 \%$ responden menjawab "setuju" dan $18,7 \%$ responden menjawab "tidak setuju".

Dari pertanyaan "Setujukah Anda jika menambahkan konten berupa permainan edukatif sebagai media berlatih?". Tujuan menambahkan konten atau materi berupa permainan edukatif ini agar proses perkuliahan tidak monoton dan membosankan. Terdapat $81,3 \%$ responden menjawab "setuju" dan $18,7 \%$ responden menjawab "tidak setuju".

Dari pertanyaan "Apakah cara dosen menyampaikan konten/materi berupa video, voice note, gambar, atau penjelasan teks mudah dipahami?". Terdapat $51,2 \%$ responden menjawab "ya" dan $48,8 \%$ responden menjawab "tidak". Dapat disimpulkan, $51,2 \%$ responden dapat memahami penyampaian materi dari dosen dengan metode kuliah daring. Sedangkan $48,8 \%$ responden kurang bisa menyesuaikan dengan metode ini.

Dari pertanyaan "Puaskah Anda dengan materi yang diberikan oleh dosen selama pembelajaran daring?". Terdapat $27,5 \%$ responden menjawab "puas" dan 72,5\% responden menjawab "tidak puas". Dapat dilihat perbandingannya, bahwa banyak mahasiswa yang tidak puas dengan metode dosen dalam memberikan materi selama kuliah daring.

Dari pertanyaan "Menurut Anda, apa yang harus menjadi acuan bahwa mahasiswa paham dengan materi yang diberikan, dan dosen dapat melanjutkan ke materi selanjutnya?". Terdapat $65 \%$ responden menyatakan yang menjadi acuan adalah antusias mahasiswa dan dari $35 \%$ responden menyatakan dengan hasil latihan soal. Dari pertanyaan "Apakah menurut Anda sistem pembelajaran daring saat ini sudah memuaskan?". Hanya terdapat $20 \%$ responden yang merasa puas dengan dengan sistem kuliah daring saat ini. Sedangkan $80 \%$ responden merasa tidak puas dengan sistem kuliah daring.

Dari pertanyaan "Jika Anda diminta untuk memilih, Anda lebih suka pembelajaran daring atau tatap muka?" terdapat $93,8 \%$ responden memilih perkuliahan tatap muka dan $6,2 \%$ responden memilih sistem perkuliahan daring. Dapat disimpulkan bahwa hanya 6,2\% responden yang menikmati perkuliahan daring.

Dari pertanyaan “Apa motivasi Anda saat sedang malas mengikuti pembelajaran daring?". Kebanyakan responden termotivasi dengan orang tua, keluarga, nilai, dan biaya UKT (Uang Kuliah Tunggal) yang mahal. Banyak sekali motivasi yang dilontarkan oleh responden untuk menyemangati diri sendiri ketika merasa malas mengikuti kuliah daring. Berikut beberapa motivasi yang dinyatakan oleh responden:

a) "Mengingat orang tua karena mereka telah banyak mengeluarkan biaya dan susah payah bekerja."

b) "Berkaca pada uang UKT yang begitu mahal".

c) "Ingat usaha orang tua untuk mengkuliahkan saya."

d) "Jika saya malas mengikuti pembelajaran daring ataupun tatap muka, saya selalu mengingat kata-kata dari Imam Syafi'i yaitu "Barangsiapa tidak mau merasakan pahitnya belajar, ia akan merasakan hinanya kebodohan sepanjang hidupnya."

e) "Tidak ada kesuksesan tanpa perjuangan."

Dari pertanyaan "Apa yang Anda lakukan saat masih belum memahami materi namun jam kuliah daring telah selesai?" banyak responden memilih mencari pemahaman lain di berbagai sumber seperti buku, youtube, maupun google. Ada pula responden yang memilih untuk memahami sendiri dan mengulang penjelasan dari dosen. Namun, tidak sedikit respoden memilih bertanya kepada dosen yang bersangkutan atau berdiskusi dengan teman.

Keberhasilan penerapan e-learning sebagai media pembelajaran daring di perguruan tinggi ditunjang oleh adanya interaksi yang maksimal antara mahasiswa dan dosen, antara mahasiswa dengan berbagai fasilitas pembelajaran daring, antara mahasiswa dengan mahasiswa lainnya, dan adanya pembelajaran aktif dalam interaksi tersebut. Tidak hanya itu, mengingat motivasi merupakan motor penggerak dalam perbuatan, maka diperlukan motivasi belajar yang harus ditanam dalam diri, terutama motivasi yang berasal dari mahasiswa itu sendiri. Kuat lemahnya motivasi belajar seseorang ikut mempengaruhi keberhasilan belajar.

\section{KESIMPULAN}

Dari hasil penelitian, masing-masing mahasiswa Tadris Matematika atau Pendidikan Matematika memiliki respon berbeda terhadap penerapan e-learning sebagai media pembelajaran daring di perguruan tinggi di tengah wabah Covid-19 saat ini. Meskipun 80 responden telah melakukan pembelajaran daring, namun ada yang setuju dan tidak setuju, ada pula yang puas dan tidak puas dengan adanya sistem pendidikan daring. 
Bahkan, 48,8\% dari 80 responden merasa kesusahan dalam memahami materi yang diberikan dosen. Oleh karena itu, motivasi belajar diperlukan agar mahasiswa memiliki dorongan dan semangat untuk lebih memahami materi dari dosen khususnya materi Tadris Matematika atau Pendidikan Matematika.

\section{DAFTAR PUSTAKA}

Ahmad, Hanafi (2011). Media Sosial sebagai Penunjang Proses Perkuliahan. Yogyakarta: Sekolah Tinggi Manajemen Informatika \& Komputer Jendral Ahmad Yani Yogyakarta.

Boyd, Danah (2009). Living and Learning with Social Media, Symposium for Teaching and Learning with Technology. Penn State: State College, PA.

Guetterman, T.C. (2015). Descriptions of Sampling Practices Whitin Five Approaches to Qualitative Research in Education and the Health Sciences. Forum: Qualitativ social research, 16(2), 25-26.

Hanum, Sulistyo (2013). Keefektifan E-Learning Sebagai Media Pembelajaran. Jurnal Pendidikan Vokasi. 3 (1): 43-44.

Horton, William \& Horton, Katherine (2003). E-Learning Tools and Technologies: A Consumer Guide for Trainers, Teachers, Educators, and Instructional Designers. USA: Wiley Publishing, Inc.

Indah, S. (2019). Pemanfaatan E-Learning sebagai Media Pembelajaran di STIA Al Gazali Barru. Meraja Journal. 2 (1), 2-3.

Mailangkay, Adele B. L. \& Suharyanto (2016). Penerapan E-Learning sebagai Alat Bantu Mengajar dalam Dunia Pendidikan. Jurnal Ilmiah Widya. 3(4), 15-16.

Miarso, Yusufhadi (2004). Menyemai Benih Teknologi Pendidikan. Jakarta: Prenada Media.

Pratama, Anang (2016). Pemanfaatan E-Learning Berbasis Telegram dalam Pembelajaran Bulutangkis. Prosiding Seminar Nasional Maret. 